\title{
EDUCATION POLICY FOR GLOBALIZATION: THE MALAYSIAN EXPERIENCES
}

\author{
Alis Puteh, \\ Ahmad Zaidi Johari, \\ Subhan M.Meerah \\ alis@uum.edu.my, Education Studies, UUM CAS, Malaysia
}

\begin{abstract}
Phillipson (1998) argued that "globalization policies serve to ensure that the role of English is maintained and perpetuated. The key player in educational policy is the World Bank." Mazrui (1997) said "the World Bank's real position...encourages the consolidation of the imperial languages in Africa. Its strategies for stabilising and revitalising universities absolutely do not mention of the place of language at tertiary level of African education." According to Stiglitz (2002), "the IMF, the World Bank and the WTO were the three main institutions that govern globalization....they also have been at the centre of the major economic issues for the last two decades". According to Coulmas (1992), the spread of English is linked to modernisation in two ways. Firstly, English is seen as a central tool by which the process of modernisation (globalization) can be achieved particularly in developing societies. Secondly, monolingualism (English) is seen as a practical advantage for modern societies while multilingualism is viewed as a characteristic of traditional societies. The main issue in language policy in any country, especially those categorised as third world countries, is whether the policy is formed according to the agenda of the normal populace or the trans-national corporations. Spring, (1998) argued that "in this scenario elites need to be proficient in English in order to serve their own and global interest, and local languages must facilitate internal policing of an export - oriented economy and attempt to limit social unrest so that this economy can persist. Trans-national corporations are increasingly active in determining the content of education worldwide." Stiglitz (2002) also claimed that "globalization is powerfully driven by international corporations." This development illustrates how the needs and will of these trans-national corporations give rise to producing customer-like citizens more than critical citizens.
\end{abstract}

Keywords: Education Policy, Globalization, Medium of Instruction Policy

\section{Introduction}

As the main key of cultural reproduction, it is appropriate for the World Bank and the trans-national corporations to use education to strengthen and widen their influence. During the Colonial years, English was promoted in these colonized countries as an international communication language - a language to be used for the development of the economy, unity, and others. In the era of globalization today, the English language has achieved this objective as was desired by the colonizers before, to the extent of virtually dominating the global culture and linguistic ecology, while at the same time, many languages are losing their natural speakers and users which would eventually fade away.

Fishman (1996) saw that "the socio-economic factors that are behind the spread of English in most countries of the world and the continued spread of English in former colonies is related more to their engagement in the modern world economy then to any efforts derived from their colonial master." While, Phillipson (1998) added that "it means a western-dominated globalization agenda is set by the trans-national corporations and the IMF and the US military intervening where The World Bank, NAFTA, and WTO policiescontribute to political instability thus provide less favourable conditions for education, democratisation, cultural and linguistic diversity."

In post colonial and post communist settings, educational policy should have multilingual aims and means and build on local resources rather than being articulated in terms of the false dichotomy (Fishman, 1968) between a local language and English. According to Stromquist and Monkman (2000), "innovations affecting the schools, curricula, teacher education, educational governance, and higher education can be linked to globalization initiatives." Normally, the global process can affect the national educational system indirectly as well as directly. In view of the global forces impinging on national economic, political and cultural contexts, governments have to respond by initiating educational changes to meet these global imperatives. At the same time, there are direct effects of globalization on education systems. Nation-states tend to follow global trends on education through institutional isomorphism and educational borrowing. 
ISSN 2411-9563 (Print) ISSN 2312-8429 (Online)
European Journal of Social Sciences Education and Research
September-December 2014

Volume 1, Issue 2

According to Davies and Guppy (1997:438), "there are two sets of arguments as why globalization would have some significant effects on educational changes, one being economic globalization and the other global rationalization". The effect of globalization on the potential development of a country depends on the ability of its education and human resource. There are new markets that require better quality products, high technology jobs requiring very skilled labour forces, and rapidly changing tastes, all of which will result in flexible and specialised production and greater worker responsibility. So, the market forces are driving educational reforms. According to Carnoy (2000) "the globalize market creates a worldwide demand for certain kinds of skills such as language, mathematical reasoning, scientific logic and programming, which are associated with higher levels of education."

Globalization should have a profound impact on education because two of the main bases of globalization are knowledge intensive information and innovation. Yet, education does not seem to have changed much at the classroom level. Globalization might be mainly economical or at the same level, political without touching deeply entrenched national institutions such as the formal educational system (Carnoy, 2002). However, in several third world countries, there are great changes witnessed in their respective educational systems where globalization has caused the modification of their medium of instruction policy from using their respective national language to English.

According to Kunio (2000), for a developing country, globalization means the increasing presence of foreign companies that rely heavily on English and the language of communication. When the national economy continues to weaken, more students will pursue their education in English and will be separated from the students that are taught using their mother tongue. When this division occurs, those left at the mercy of the market forces and globalization may be politically unified which will stop future uncertainty and liberalisation. In the extreme, they may even force the government to take a step backwards, and when this occurs, the economy will stop or face a downturn.

According to Daun (2002), a country can respond to globalization in many different ways. The way a country reacts would influence the effect of globalization on education. In general, the reaction of education towards globalization depends on three main factors, which are the economic status, the interpretation of population towards an event, and their ideology towards the role of the public sector and education. In several cases, it was observed that the curriculum content and the medium of instruction had become more diverse.

\section{Malaysia Education System}

There is a common phenomenon to all colonized countries, that is, all inherit the educational model of the metropolitan power. Colonial powers in most cases disrupt the traditional educational systems of the colonized and supplement them with systems based on imported models. Miller (1989) viewed that the formal educational policies of India, Sri Lanka, Burma and Malaysia were mould on the English pattern, those of Indo-China on the French, those of Indonesia on the Dutch, and those of the Philippines on the Spanish patterns. The British colonial system of education made its impact on almost every aspect of the education in the colonized countries. In the aspect of curriculum, its contents were almost a carbon copy of that used in the then aristocratically oriented British system. As such, it was, as many authors have generally conceded, not in tune with the pupils' environment nor practical use in their lives (Tuqan, 1974; Altbach, 1978).

According to Bakri (2003), "schools were along racial lines during British. Malay schools were consumed with religious studies and limited to primary level only. Chinese schools were nothing more than fronts for the Communist Party. Tamil schools might as well have been in Tamil Nadu, India. Only the English schools had a multiracial student body. But they were few and necessarily elitist". The colonial system never held out the prospects of integration into indigenous culture to those who attended their schools. The colonial system or schools were marked by diversity (Altbach,1978).

All the National-Type schools in the country had to undergo a change in their language media of instruction to Malaysia Language. The result of this change will be the conversion of National-Type Schools into National Schools. The first conversion was launched in January 1968 with the conversion of English primary schools to National Schools (State the name of the school). The conversion was conducted in stages, by first teaching five subjects in the Malay language in Standard one (I) to three (III) in National-Type English Primary Schools. By 1970, all subjects except English were taught in Malay in Standard one (I). Malay-medium classes had also started in secondary vocational schools in 1968 and in 
secondary technical schools in 1970. And from 1983 all courses in the local universities were progressively converted to the national language (Table 1.1).

Table 1.1: Malay language as a Medium of Instruction In Malaysian Education System.

\section{Implementation}

National Language was made a compulsory subject at all levels in all assisted primary and secondary schools

The establishment of Malay-medium secondary classes which eventually developed into National Secondary Schools.

i) The establishment of the first fully residential Malay-medium Secondary School in Kuala Lumpur Alam Shah National Secondary School.

ii) Malay -medium Sixth Form Classes started in Shah Alam National Secondary, Kuala Lumpur.

First batch of Malay-medium pupils admitted to University of Malaya

i) First batch of Malay-medium students graduated from University of Malaya.

ii) Malay-medium classes in Secondary Vocational schools.

iii) Five subjects taught in Malay Language in Standard 1-3 in National-Type English Primary Schools.

Civics taught in Malay Language in Standard 4 in National-Type English Primary Schools.

i) All subjects in Standard 1 taught in Malay Language in National-Type English Primary Schools.

ii) Geography and History taught in Malay Language in Standard 4 in National-Type English Primary Schools.

iii) Malay-medium classes in Secondary Technical Schools.

All Arts subjects in Form 1 taught in Malay Language in National-Type English Primary Schools.

i) No more English-medium Remove classes

ii) National-Type English Primary Schools were fully converted to National primary Schools.

i) All Arts, Science and Technical subjects in Form 1 taught in Malay Language in National-Type English Secondary Schools.

ii) All Arts subjects in Form IV taught in Malay Language.

Arts streams in Form VI (Lower) taught in Malay Language in National-Type English Secondary Schools.

First year in Arts and allied courses taught in Malay Language in the Universities.

All Arts, Science and Technical streams in Form VI (Lower) taught in Malay Language in NationalType English secondary Schools.

National-Type English Secondary Schools fully converted National Secondary Schools.

First year in all courses (Arts, Science, Engineering, Medical, etc.) taught in Malay Language in Universities. 
ISSN 2411-9563 (Print) ISSN 2312-8429 (Online)
European Journal of Social Sciences Education and Research
September-December 2014

Volume 1, Issue 2

Source: Ministry of Education, 2002

The medium of instruction in Malay is judged to be successful. It has produced graduates and professionals that help to develop the country. The Malay scholars had created a lot of terms in biology especially for animal and tree name. For example, since 2001 Dr. Mohammad Salleh a world standard professor from entomology, UKM had created hundreds of terms in Malaysia. A group of the beetles were being named with Malay words such as Arthrotushijau, Atrachyahitam, Dercetinabopeng, Itylusbiru, Ophridakuning, Monoleptamerah, and Sphenoraiatompok; and other words such as Sarawakiolaajaib, Medythiabukit, Monoleptacantik, Nadranadwiwarna, Podontiajalur, Pseudosastraindah, Monoleptakenit, trichomimastrakurnia, Xenodalapan, Paleosepharialawa, Metrioideamolek and Liroetiellwarisan; and from a place such as Aplosonyxpahangi and Malay name such as Arcariesismaili. All the terms were recognized by international body and indirectly recognized Malay as international science language (UKM,2004).

The Ministry of Education reintroduce English as a medium of instruction to teach Mathematics and science in all schools, colleges and universities. The stress on English medium on the other hand show that British colonial belief that language can change one's pattern of the output and to see things differently (Barbour, 2000). British wanted as many as Malayan people studied in English medium because it would help the colonial to administrative Malaya pre-independence and postindependence. This objective was fruitful because after 53 years independence, many of the English educated still believe learning English as the best way to face globalization. From the Fifth Educational Conference of 1939, it was shown that the English language was the one great unifying principle in Malaya, while the English schools had the important cultural role and place in the making of Malaya.

This differential valuation as exchange systems between two streams has posed a serious obstacle to Malayan government's stated goal of transforming the Malay medium stream into a unified National School System. After 53 years of independence, the Malay medium schools are National Schools, only by name. Located primarily in rural areas and drawing their student enrolment almost exclusively from the Malay community, the national schools and public higher institutions continue to provide extremely limited access to modernized occupations as compared to the private schools and private higher institutions which used English as their medium of instruction.

The continued weakness of Malay language education relative to that of English has an important political implication due to the fact that this factor has served to undermine the legitimacy of the Alliance government among some important sectors of the Malay community. On the other hand, however, if the government were successful in rapidly reversing the value position of Malay education vis-à-vis the other language streams, it would be in danger of losing the tenuous legitimacy granted to it by the non-Malay communities.

At the tertiary level of education, the policy makers have indicated that the higher education reform is vital to help realize Vision 2020, the national goal to be developed, as an industrial country and to be a hub in education and information technology in the region (Najib, 1996, Fong, 1993, Johari, 1996). At this level,there is no more focus onnation building or national integration. According to Rajendran (2004), ethnic harmony is being taken for granted.

In 1995 (prior to the higher education reform), there were 48 public higher education institutions comprising eight public universities, six polytechnics and 33 teacher-training colleges. By contrast, there were 275 private colleges. In 1995, 11\% of the student age cohort was enrolled in higher education - about $50 \%$ of them were in public universities. The other $50 \%$ were either attending courses in the local private colleges (35\%) or studying overseas (14\%). In 1985, there were 15,000 students studying in local colleges, and 68,000 students studying in overseas universities, especially in the United Kingdom, the United States and Australia. The majority of these overseas students were privately funded Chinese and Indian students (Lee, 1999).

According to Gill (2004), the policy for a dual medium of instruction has serious social and political implications. Firstly, the private universities have more expensive fees when compared to public universities that receive a large subsidy from the government. This means that the students that enroll in private universities come from middle-class families and Chinese families with high income, while the majority of enrolments in public universities consist of Malays that come from the average and poor families (Gill, 2005). The long-term effect has shown that the university students will divide according to 
ISSN 2411-9563 (Print) ISSN 2312-8429 (Online)
European Journal of Social Sciences Education and Research
September-December 2014

Volume 1, Issue 2

the socio-economic strata and more often than not, the ethnic groups. Thus, the medium of instruction policy would give rise to class and racial division, and not unify the Malaysian citizens.

The dual medium of instruction policy has also caused public university graduates to be at a disadvantage when looking for work in the private sector due to their weak command of the English language. This policy type would cause the Malays graduates to be unable to compete with the Chinese graduates from the private universities. Also, the private companies would be more interested in hiring Chinese graduates than Malay graduates since the majority of the private companies are owned by the Chinese. Yet again, the policy regarding the medium of instruction tends towards the division rather than unification of races.

\section{Conclusion}

Rustam (2002) had viewed the nostalgic return to the golden era of revering the English language amongst the general populace as being creole and as a crisis in tradition. The creation of a liberalised cultural policy and an unprofessional language policy will cause cultural contamination.For example, many individuals have returned to the craze in naming housing areas, corporate buildings, hotels, banks, schools, cities, and the like with western or foreign sounding names in keeping up with globalisation. Eastern and nationalistic names are considered by this group to be less attractive to customers, even to the extent that it will complicate international relations. If this group of individuals were to triumph, then surely this would mean the end for the Malay language.

In actual fact there is nothing special about the English language with respect to the level of education of a student and in scientific discovery and advancement. This is especially obvious in the scientific field, as the number of important researchers and scientists who have made important discoveries are not dominated by native English speakers, or by English trained individuals. For example, the current joint Nobel Peace Prize winners for Chemical Engineering are Koichi Tanaka from Japan, John Fenn from the United States and Kurt Wuethrich from Switzerland. Tanaka is 43 years old and is the fourth winner from Japan for the past three years and does not hold a PhD (BeritaHarian, 10.12.02).

The expansion of scientific knowledge after the $13^{\text {th }}$ century was achieved according to the language of the scientists. The German scientists recorded their findings in German, the English in English, and the Swedish scientists in Swedish, and so on and so forth. However, in the midst of the multitude of languages there existed a force to find common ground from the knowledge perspective, like getting a legitimate academic verification for each new finding.

Therefore, it is not surprising to find that the advancement of Science during the $20^{\text {th }}$ century had occurred rapidly in many different languages: English, German, Russian, French, Japanese, Chinese and many other languages including BahasaMalaysia in Malaysia which was pioneered by the National University of Malaysia (UKM). Using scientific knowledge recorded in the Russian language, the world has witnessed the first successful space ship built by mankind - the Sputnik was built by Russia and piloted by Yuri Gagarin, the first man in space. Scientific discoveries recorded in English had led to the creation of Apollo II, which brought mankind to the moon. In French, the French scientists had invented the nuclear bomb and had carried out tests in the Pacific Ocean (Shamsul Amri,2002).

The same was observed in the field of Medicine, a branch of applied science. Many important studies had been performed and paramount discoveries had been accomplished in this field, which were carried out as separate research in different languages. The researchers in Japan, including the Nobel Prize winners, had performed their researches in Japanese. The Spanish researchers who were successful in the advancement of several new fields in Pharmacy and Medicine had recorded their findings in Spanish. Obviously the researchers in Australia, Canada, United Kingdom and USA had used English.

In the field of Mathematics, there are many child prodigies below the age of ten and some in their early teens around the world who are granted scholarships in several universities, (like Sofia, a Malay girl studying at the Oxford University) each individual continuing their respective studies. It is obvious that language is not a matter of serious consideration when the universities are dealing with cases such as these.

If we were to say that only one language is responsible for the success in Science, then it would go against history. It would also be foolish to use scientific knowledge to learn a language; which is unheard of anywhere in the world. If we were to review the process of learning a language and the spread of scientific knowledge in various languages above, we would 
conclude that the two fields are world apart and to use one in an attempt to improve the other would be an incredible flight of the imagination (Hassan,2002).

In conclusion, most of the former Western colonies have not progressed even though they have used Western languages as their official or main language in their system of education. Malaysia, Indonesia, Japan, South Korea, Taiwan and Thailand use their own native languages fully in each of their respective countries. These countries are developed, or currently developing, or at the very least are not included in the list of Least Developed Countries (LDCs) which include 40 former Western colonial countries.

There are many other factors other than language that contribute to the economic development of a country. Some of factors include the capability, honesty, trustworthiness of the government leaders and the natural resources of the country. Fishman's view is obviously influenced by traditional evolutionary Western thinking that assumes a modern language, like English, can bring progress to developing countries. This is the ethnocentric attitude and Western colonial mentality that is consciously or subconsciously expressed through the language planning theory that uses the Western model of progress as the criterion to define the function of language development. The essence behind this theory can be put aside since most of the countries that use English, French or Spanish (that are said to be advanced) as the official language, still have not progressed, and some still stricken by poverty, while several other countries that use their national/official language have become or are becoming developed.

\section{References}

[1] Alidou, H. 2004, 'Medium of instruction in post-colonial Africa', in Medium Of Instruction Policies, eds., J.W. Tollefson and A.B.M. Tsui, LEA, New Jersey.

[2] Alis, P. 2004, 'Nationalism and Nationism: A Study of Language Medium Policy in Malaysia'. Paper presented at $36^{\text {th }}$ World Congress of IIS in Beijing, 7-11 July.

[3] Annamalai, E. 2004, 'Medium of power: The question of English in education in India', in Medium Of Instruction Policies, eds. J.W. Tollefson\& A.B.M. Tsui, LEA, Mahwah, NJ.

[4] Chai, C.H. 1971, Planning Education for A Plural Society, UNESCO Institute For Educational Planning, Paris.

[5] Carnoy, M.2002, 'Latin America: the new dependency and educational reform'. In Educational Restructuring in the Context of Globalization and National Policy, H. Daun, Routledge, NY.

[6] Daun, H. 2002, Education Restructuring in the Context of Globalisation and National Policy, Routledge, London.

[7] Davies, S. \& Guppy, N. 1997, 'Globalization and educational reform in Anglo-American democracies', Comparatives Education Review, 41:4, pp 435-59

[8] Enloe, C. 1973, Ethnic Conflicts and Political Development, Little Brown, Boston.

[9] Fishman, J.A. \& Fishman, S.G. 2000, 'Rethinking language defence', in Rights To Language: Equity, Power and Education, ed. R. Phillipson, LEA, NJ, Pp. 23-27.

[10] Gill, S.K. 2004, 'Medium of instruction policy in higher education in Malaysia vs. internationalization' in Medium of Instruction Policies: Which Agenda, Whose Agenda, eds., J.W. Tollefson\& A.D.M Tsui, LEA, New Jersey, Pp. 135-152.

[11] Halliday, M.A.K. 1975, Learning How to Mean, Explorations in the Development Of Language, Edward Arnold, UK.

[12] Hassan, A. 2002, 'Dasar bahasa dan peranan negara di Malaysia', Siri Bicara Bahasa, No. 9, DBP, Kuala Lumpur.

[13] Kunio, Y. 2001, Globalization and National Identity, UKM Publishers, Bangi.

[14] Nababan, P.W.J. 1981, 'Language perception and medium of instruction', In NL As Medium Of Instruction, 
EdsAsmah Omar \& Noor Ain Nor, DBP, KL.

[15] Pennycook, A. 2002, 'Language policy and docile bodies: Hong Kong and governmentality', In Language Policies In Education, Ed J. Tollefson, LEA, NJ, Pp. 91-110.

[16] Phillipson, R. 1992, Linguistic Imperialism, Oxford University Press, Oxford, UK.

[17] Ranaweera, A.M. 1976, 'Sri Langka: Science teaching in the national languages' in Prospects, vol.3, pp.416423

[18] Snodgrass, D.R. 1980, Inequality and Economic Development In Malaysia, Oxford University Publishers, KL.

[19] Skutnabb-Kangas, T. 1999, 'Human rights and language wrongs a future for diversity', Language Sciences, Vol. 20, No. 5. pp. 112-123.

[20] Sotomayer, M. 1977, 'Language, culture and ethnicity in developing self- concept', Social Casework, 58, vol.1, pp 195-203.

[21] Smith, A. 1998, Nationalism and Modernism, Routledge, London.

[22] Spring, J. 1998, The Sorting Machine Revisited: National Education Policy Since 1945, Longmans, NY.

[23] Stromquist, N.P. \&Monkman, K. 2000, Globalization and Education: Integration and Contestation Across Culture, Rowman, Lanham.

[24] Shamsul, A.B. 2003, One State, A Few Nations and Many Languages: Language Identity, Formation and Nation Construction In Malaysia, paper presented at Solls, KL, 16-19 December.

[25] Tollefson, J.W. \&Tsui, A.B.M. 2004, Medium Of Instruction Policies: Which Agenda, Whose Agenda, LEA Publishers, NJ.

[26] UKM, 1989, The Process Of National Integration In The Education Setting, Faculty Of Education, Bangi

[27] Water, M. 1995, Globalization, Routledge, London. 